\title{
Tourism Policy and Enabling Conditions; A Comparative Analysis Related to Mediterranean Destinations
}

\author{
Ramazan GORAL \\ Asst.Prof. Lecturer at Ali Akkanat Tourism Faculty \\ Selçuk University, Beyşehir/Konya TURKEY. \\ Phone +90 5448690991 \\ trgoral@selcuk.edu.tr.
}

\begin{abstract}
On the study, competitive position of eight destinations on Mediterranean Basin (Turkey, Greece, Italy, France, Spain, Egypt , Tunisia and Morocco ) related to Tourism Polıcy and Enabling Conditions were analyzed as comparative in terms of both index wide and also sub-factors as Data of Travel and Tourism Competition Index (TTCl) which was published by World Economic Forum in 2015 was used. According to analysis 's findings, most competitive first three destinations are respectively Spain, Greece and Tunisia in terms of general index of Tourism Polıcy and Enabling Conditions. Destinations' clmpetitive positions' order changes in terms of sub-factors. Five point likert scale was used to make meaningful country's competitive position by points that it got from criteria belonging to countries' sub-factors. Accordingly, the following points which countries got from criteria express competitive positions: $5=$ Very well, 4=Well, 3=Medium, 2=Bad,1=Very bad. Moreover, when eight destinations on Mediterranean Basin are evaluated, there is a significant relation between Tourism Polıcy and Enabling Conditions and Tourism Income and Number of Tourist in terms of statistics.
\end{abstract}

Keywords: Tourism Polıcy and Enabling Conditions, Prioritization of Travel, International Openness, Price Competition, Environmental Sustainability

\section{Introduction}

Number of company increased, number of employee people increased, income of exportation increased and sub-structure developed as relying on formation of new destination areas world wide on tourism sector and increase in investment amount which was made on tourism area. Thus tourism became an important impulse power on socio-economical development. In recent years, tourism sector has become one of economical sectors which growed and developed quickly over world. Despite of occasional shocks, tourism sector has showed nearly nonstop development for years. Number of international tourist reached 1 billion 133 thousands in 2014. In the same year, international tourism incomes of destinations world wide reached 1.246 billion USA dollar. It is expected that number of international tourist is to reach 1.8 bilion in 2030 (UNWTO, 2015).

Many tourism destinations world wide try to take a share from such a large industry. But tourism destinations face to interser competition today than one in past (Ozturk, Usakli, 2013,2). In recent years, that specific policies related to tourism sector are formed and facilitators are provided have become a factor which is evaluated in terms of competitive supremacy (World Economic Forum WEF, 2015). So it is first necessary work im the way to competitive supremacy that destinations strengths and weaknesses related to tourism policies and facilitators are determined as then they make strategie. From this viewpoint, a comparative competitive position analysis related to eight destinations on Mediterranean Basin ( Turkey, Greece, Italy, France, Spain, Egypt, Tunisia and Morocco ) was made as data of Tourism Polıcy and Enabling Conditions from indexes of World Economic Forum (WEF)' s Travel and Tourism Competition Index (TTCl) was used on the study. Relevant destinations were chosen as the logic " competition group" which was revealed by Kozak and Rimmington was used (Kozak, Rimmington,1999). There are three goals of the study : a) to review relevant destinations' Tourism Polıcy and Enabling Conditions, b) to determine relevant destinations' strength and weaknesses of Tourism Polıcy and Enabling Conditions, c) to review whether there a relation between destinations' international tourism incomes and number of tourist with points of Tourism Polıcy and Enabling Conditions (TPEC). 


\section{Literature}

TPEC's Index is mostly related to evaluate specific policies and strategic appearance on tourism sector (Crotti, Misrahi, 2015). Provisions related to TPEC are evaluated by determiner sub-factors which were prepared as specific to the sector. Sub-factors of this factor are Prioritization of Tourism, International Openness, Price Competition, Environmental Sustainability (WEF,2015).

These sub-factors and their criteria were explained in terms of making a theoretical back ground on the study . Moreover, data related to criteria on various international reports were given on the section.

\subsection{Prioritization of Tourism;}

That governments prioritise tourism to what extent has important effect on a country's competition of tourism sector. In other saying, that government accept the sector as primary sector and can transfer fund and can coordinate necessary elements and sources to develop the sector increase competition power of the sector. Stability on government policies contributes positively to the sector 's capability to get private investment. Moreover, governments can take important roles on national marketing campaigns in order to attract tourist (Crotti, Misrahi, 2015, 7). Subjects such as State's Travel and Tourism Expenses, Marketing and Branding Efforts Related to Attract Tourist, Availability of Monthly /Three-Month/Annual Travel and Tourism in Time, Country Brand Strategies etc. are evaluated on these sub-factors (WEF,2015).

State's view on tourism and scaling it. How much prior the development of tourism sector is for a government in a country is evaluated by this criteria (WEF, 2015).

Share which is separated from state's budget to tourism. Amount (\%) which is separated to tourism from state's total budget in a country is evaluated by this criteria (WEF,2015). According to data which was published by World Travel and Tourism Council (WTTC) in 2015, the budget that the state separated to tourism in countries and their ratio on total budget which were given on the study were showed at Table 1.

Tablo.1.Government Individual Travel \& Tourism Spending

\begin{tabular}{|c|c|c|c|}
\hline Unit & Country & 2015 & 2010 \\
\hline \multirow{8}{*}{$\%$ share } & Turkey & 0.100 & 0.100 \\
\hline & France & 0.500 & 0.500 \\
\hline & Greece & 7.900 & 8.000 \\
\hline & Italy & 0.700 & 0.700 \\
\hline & Spain & 1.400 & 1.400 \\
\hline & Egypt & 6.800 & 6.700 \\
\hline & Morocco & 3.600 & 3.500 \\
\hline & Tunisia & 7.400 & 7.300 \\
\hline \multirow{7}{*}{ US\$ bn } & Turkey & 0.090 & 0.070 \\
\hline & France & 2.414 & 2.465 \\
\hline & Greece & 0.030 & 0.050 \\
\hline & Italy & 1.738 & 1.977 \\
\hline & Spain & 1.961 & 2.477 \\
\hline & Egypt & 0.311 & 0.204 \\
\hline & Morocco & 0.090 & 0.070 \\
\hline
\end{tabular}


Source: (Knoema,2016)

\begin{tabular}{|l|l|l|l|}
\hline & Tunisia & 0.080 & 0.070 \\
\hline
\end{tabular}

As it is seen at Table 1, order of monetary (USA Dollar) that countries separated to tourism from their total budgets and weight (\%) of budget which was separated to tourism from total budget differ from each other. Countries ' " Ratio (\%) of total state budget which was separated to tourism" was considered on TTCI report of WEF.

Activity of Marketing and Branding Studies to Attract Tourist : Marketing and branding campaigns activity which a country conducts to attract tourist is scales within the concept of this criteria (WEF,2015). That main elements are in effort to market only their own products on tourism sector is not sufficient for country's marketing and branding activity. Marketing and branding efforts should be main duty of each part involved in tourism sector. If tourist is wanted to be attracted to a destination, promotion of destination is completely required. Destination marketing, especially a country's marketing is a common problem especially. Marketing studies related to provide visit of tourists to a country are in responsible of government which governs the country in large scale. There is synergic potential while a country is marketed as both touristic destination and also business investment area. Coordination and collaboration of instruments that state has got them are important for revealing of this synergy (AALEP,2015).

Extensity of Data on Tourism : Tourism data is evaluated by national information source which has got formal quality within the concept of this criteria (WEF,2015). Tourism data is an important source for tourism management, marketing and planning. Data is used as a helpful tool in the event that countries and tourism organisations foresee about tourism in long term and goals are made. Statistical data is very important on development of information related to tourism sector, following developments in sector, supporting management focused on result, determination of strategic terms on political decisions .

Currency of Data on Tourism: Currency of tourism data expresses the time between the end of reference term that data belongs to and the end of term that data is announced to public and is valid. Thus, currency changes as relying on length of this period. Data currency is closely related to existence of a calender related to publication of data. Sharers of public and private sector require to access statistical information related to tendencies and changes in regular and time in order to manage tourism economy actively in level of local, regional and national (UN,2008,81).

Country's Brand Strategy: Products may have got brands on geographical positions as they are. Thanks to branding, people are aware of certain geografies and so intended awareness are gotten. A destination can be defined as a name, symbol, logo, word or other terms which define destination and make it different. Destination brand bids unforgettable travel experience. At the same time, it services to remember travel experiences related to destination, pleased memories. Branding of destination has become very important in the event that certain destinations (city, region, country etc.) are positioned as their differencies are provided in terms of receivers and sharers today (Damnjanoic, Kravic and AbdulRazek, 2009).

\subsection{International Openness}

That a competitive tourism sector is made requires foreign spread in a certain scale and applications to facilitate travel. Restriction policies such as aggravated visa demands cam decrease touristic demand to country. Sub-factor International Openness involves terms such as bilateral air services contracts which would affect air transportation, regional trade contracts which would make possible to service tourism on world standards etc. (Crotti, Mısrahi,2015, 7).

Visa Requirements : Visa policies involves in most important state arrangements which affect on international tourism. Developing policies and procedures related to facilitate travel procedures such as visa and passport are related closely to development of tourism. Those who travel see visa procedures as a formality which increases expense. If necessary visa expenses to travel to a destination is high, potential tourists may tend to alternative destinations which they meet less difficulties on visa procedures (UNWTO, 2016, 7).

Bilateral Air Services Contracts : More than half of international tourists reach to destinations that they choose, by airlines and more than 23 million tourists will attend in those who travel by airlines in each year in that period up to 2030 according to UNWTO. Thus, forming policies about air services and developing bilateral contracts, connections with other countries can seen as a tool related to more competitive tourism sector (Rifai, 2011,4). 
Valid Regional Trade Contracts : Regional trade contracts are defined as mutual trade contracts between two or more parties. Free trade regions and customs unity contracts are involved in these contracts. Countries may make better conditions to access market and provide security as party to trade contracts that World Trade Organisation foresees for tourism service provider and investments.

\section{Price Competition}

Low expenses are factor to make attractive that tourists travel a country and also incite investment on the sector. Within the concept of price competition; Taxes which are taken from airplane tickets, Airport Prices, Comparative Hotel Accommodation Expenses, Parity of Purchasing Power, Other Expenses Records Which Affect on Travel Expenses are included (Crotti, Mısrahi, 2015, 7). Price Competition is accepted as one of most important terms of competition power generally for a certain destination (Falzon,2012).

Ticket Taxes and Airport Prices: Tourism and aviation are two contract subjects to each other. In another saying, Taxes which are implemented on services of air transportation would affect negatively on tourism which is vital for many countries' economy. Many studies have showed that those who travel among all traveling persons consist most sensitive part to price. Thus, large decreases will occur in demand in the event that an expense increase occur in aviation services. For example, a price increase as $10 \%$ will cause a decrease as $15 \%$ supposedly on travels with touristic purpose. As a result, demand will be affected negatively in large scale. Even if income which is obtained from these taxes is assigned to tourism ' $s$ promotion to foreign countries, these promotion campaigns will not be used for anything but for returning number of tourists who visit country previously but do not come due to aviation prices and ticket taxes, to a previous condition (IATA).

Price of Hotel: Expense of touristic travel to a tourist involves expenses such as transportation services' expense on arrival on destination and returning from it, accommodation, tour services, food and beverages, entertainment. These expenditure items are related closely to travel desicion. Relative expense increase on middle and long terms can cause losses of market share on a certain destination and contrastly, decrease in relative expenses can cause increase in market share also (Dwyer, Forsyth and Rao,2001,3). If hotel prices have important place among touristic expenditure items, it can be said that Hotel'de relative price levels would affect on taking decision for travel to a certain destination.

Parity of Purchasing Power: Parity of Purchasing Power (PPP) is an exchange ratio which makes equal purchasing power of different currency as it removes different price levels among countries. PPP is counted as ratio in sum of national money which requires that a certain good and service basket are bought. Expenses which are turned to different currency as using this ratio provide comparable data in real meaning among countries as expenses reflect differencies in good which is bought and service volume (TUIK, 2008,1). Relative change of certain destination ' $s$ expenses to other destinations and changes in Parity of purchasing power are accepted as most important factors which have got effect on destination shares of total abroad travels (Dwyer, Forsyth and Rao,2001,3) .

Price Level of Fuel: Change in fuel prices ( in transportation, production expenses, economic process ) may damage tourism events due to expenditure effect. Researches conducted have showed that high fuel price has got negative effect on tourism. High fuel price may affect negatively on some parts (airline, tourist navigation etc.) more than others (Chatziantoniou et all,2013).

\section{Environmental Sustainability}

Importance of natural environment can not be ignored on attractiveness of touristic destinations. So policies and relevant factors which are developed for continuity of environmental sustainability will continue natural attraction of a country and also in the future, they are important on protection of attraction as touristic destination and obtaining competition advantage (Crotti, Mısrahi,2015, 7). This sub-factor includes sub-itles such as Environment Legislation and Application, Sustainability of Developments Related to Travel and Tourism Sector , Certifying Environmental Contracts, Species under Treat (WEF,2015).

Frequency of Environmental Arrangement and Application of Environment Legislation : It causes productivity growth as environmental arrangements have got impulse on cleaner environment and novations. Moreover, early adaptation to eco-friendly technologies and early investments of countries would provide comparative advantages on industries which are sensitive to environment . Adapting strict environment legislation arrangements may guide about structural adaptation especially for developing countries (Ratnayake, 1998, 77-78). 
Sustainability of Tourism' s Development: Sustainable Tourism may be stayed as ' tourism events which meets needs of visitors, people who are host, sector and environment and consider exactly tourism 's economic, social and environmental effects today and in future'. (UNEP and UNWTO, 2005). Sustainability of Tourism Development is possible with the case that sustainable tourism development terms and management applications can be applied in all type of tourism and destinations as to involve mass tourism and various niche tourism segments. Terms of sustainability states tourism development in terms of environmental, economic and socio-culture and a balance should be made among these three sizes in order to guarantee sustainability of tourism in long term. Sustainable Tourism development requires a powerful leadership in order to establish a wide participation and agreement besides informed attendancy of all relevant sharers. Sustainable Tourism development is a process which requires to have continuity and to be followed constantly. It is a process which requires to be preventive and /or corrective precautions taken (UNEP and UNWTO,2005, 11-12).

Particles Substance Concentration: This criteria is also stated as Population Weighted Exposition to Environment Pollution (2.5PM) and it is defined as country population ' $s$ exposition average to air-hung particles concentration. Within the concept of this criteria, particles substance concentration which its aerodynamic diameter is at least 2.5 microns which would cause heavy health problems as diffusing in deeps in respiratory tract should be considered ( World Bank). Harmful substances which occur during industrial and agricultural production and other economic events have revealed significant weather, water and soil pollutions. People who live in large cities and industrial areas where their enviroments are significantly destroyed want to take a rest in unsoiled beauties out of work and on holidays. So clean weather is an important natural tourism source (Anze,Yunting and Young, 2015, 75).

Environment Contracts: This criteria measures how many international environment contracts of total 27 contracts a country is member (WEF,2015).

Water Stress: Baseline water stress is available annual total renewable failure rate of annual total water use in industry, agriculture and for municipal water services. This rate is an important sign to evaluate risks related to water. Baseline water stress provides information about competition level among users ( industry, agriculture and municipalities ) and source decrease rates(Gassert,et al, 2013, 3).

Species Under Threat: This criteria uses the reference "The International Union for Conservation of Nature (IUCN), Red List of Threatened Species"and and is calculated at the rate of species which are under critical threat , under threat and unguarded to total mamals, birds and amphibians (WEF,2015).

Refinement of Waste Water: This criteria states waste water rates refined before re-oscillation into eco-system. Waste water refinement rate expresses civic waste gathering and refinement systems in large scale (WEF,2015).

\section{Theoretical Frame}

One of four main indexes which constitute TTCI is Tourism Policy and Enabling Conditions. This index has got 4 subfactors as to be Prioritization of Tourism, International Openness, Price Competition, Environmental Sustainability. These factors are related to evaluate specific policies and strategic appearance mostly about tourism sector. TPEC Index and sub-factors which are considered on the study are showed at Figure-1 with information which is involved in literature. 


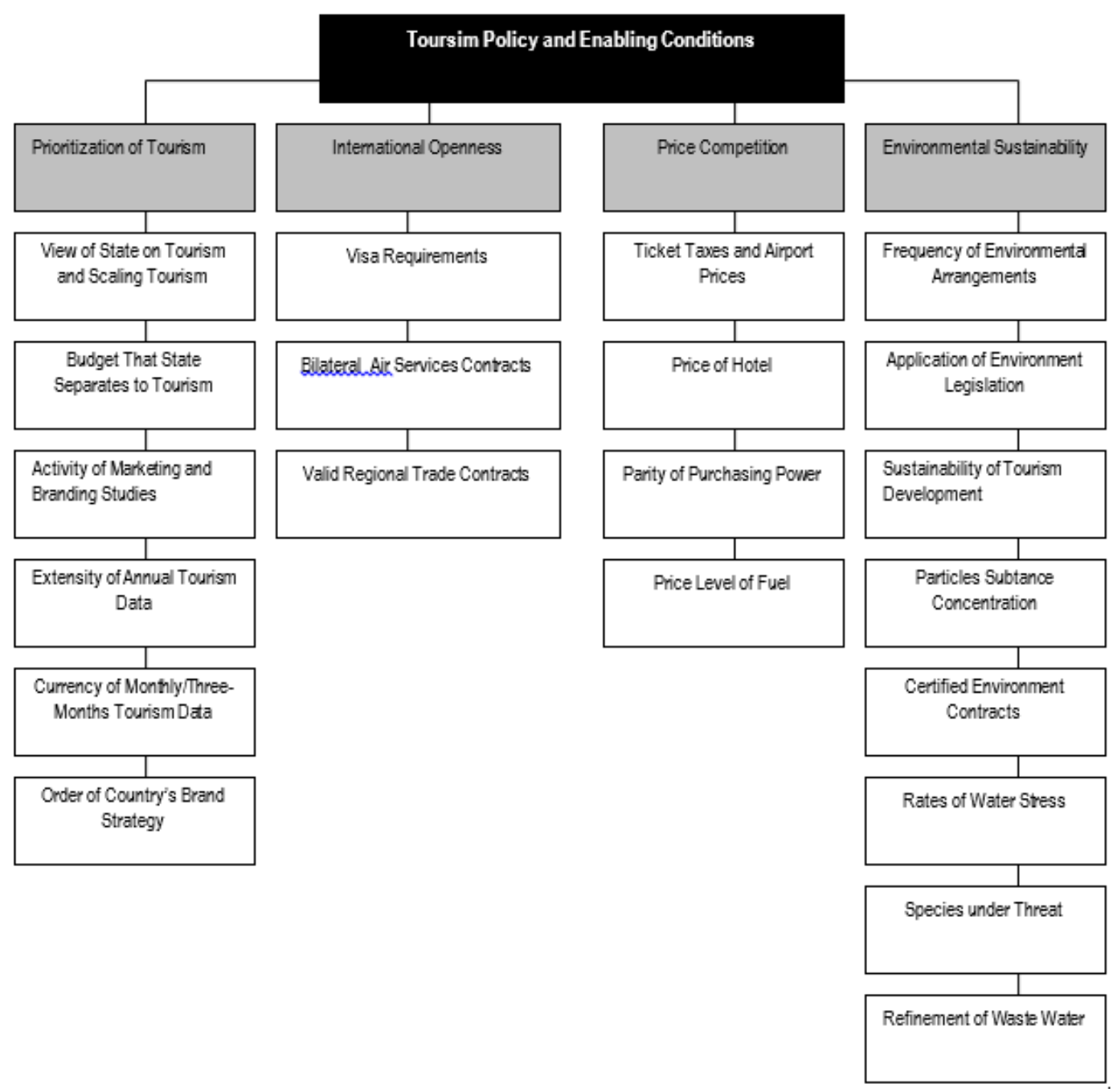

Figure.1. Index of Tourism Policy and Enabling Conditions (TPEC)

\section{Research Methodology}

Data and information related to data gathering method from secondary source have been reached on this study. Information and data are based on the report of Travel and Tourism Competition Index which was published by World Economic Forum in 2015 , in large scale. Furthermore, other national and international reports and publications have been utilized. It is a study that important industry and think tanks is involved in WEF's report and it involves deep analysis related to tourism ' $s$ future and countries ' competition. Information on the report is based on data related to 141 countries' tourism and travel sector and a survey study which was made to people who work as high level. Information and survey studies were evaluated with total 4 main groups, 14 sub-groups and total 90 scales belonging to these sub-groups (WEF,2015). On this study, competitive position of eight destinations on Mediterranean Basin ( Turkey, Greece, Italy, France, Spain, Egypt, Tunisia and Morocco ) related to TPEC index was analyzed as comparative in terms of both index general and also sub-factors ( Prioritization of Tourism, International Openness , Price Competition, Environmental Sustainability ) as using WEF's Travel and Tourism Competition Index data. 
Moreover, five point likert scale was used as to make country's competitive position as meaningful by points that countries got from criteria belonging to sub-factors. Accordingly, points that countries got from criteria were turned into five-items system. On the scale, 5 is for very well, 4 is for well, 3 is for medium, 2 is for bad and 1 is for very bad to state competitive positions.

On the study, it is also evaluated whether there is a relation between competitive positions and international tourism income of destinations on Mediterranean Basin and number of tourist within TPEC or not.

\section{Findings}

\subsection{Comparison of Destinations ' Competitive Positions}

As it is seen at Table 1, while Spain which is from Mediterranean Basin has got Very Well competitive position by general grading of Tourism Competitiveness Index, TPEC Index, other countries have got Well competitive position.

Table.1. Index General of Tourism Policy and Enabling Conditions

\begin{tabular}{|l|l|l|l|l|l|l|}
\hline & $\begin{array}{l}\text { Ranking } \\
\text { of } \\
\text { Countries }\end{array}$ & $\begin{array}{l}\text { Very } \\
\text { Well }\end{array}$ & Well & Medium & Bad & Very Bad \\
\hline Spain & 1 & 4,66 & & & & \\
\hline Greece & 2 & & 4,39 & & & \\
\hline Tunisia & 3 & & 4,28 & & & \\
\hline France & 4 & & 4,25 & & & \\
\hline Eygpt & 5 & & 4,23 & & & \\
\hline Morocco & 6 & & 4,21 & & & \\
\hline Italy & 7 & & 4,14 & & & \\
\hline Turkey & 8 & & 3,98 & & & \\
\hline
\end{tabular}

First one of sub-factors related to TPEC Index is Prioritization of Tourism. Comparative cases of destinations are at following in terms of these sub-factor;

As it is seen at Table 2, Morocco, Spain, Greece and Tunisia have got Very Well competitive position in terms of subfactors in Prioritization of Tourism. Egypt has got Medium competitive position. Other destinations have also got Well competitive position.

Table 2. Sub-factor Prioritization of Tourism

\begin{tabular}{|l|l|l|l|l|l|l|}
\hline & $\begin{array}{l}\text { Ranking } \\
\text { of } \\
\text { Countries }\end{array}$ & $\begin{array}{l}\text { Very } \\
\text { Well }\end{array}$ & Well & Medium & Bad & Very Bad \\
\hline Morocco & 1 & 5 & & & & \\
\hline Spain & 2 & 4,92 & & & & \\
\hline \multicolumn{7}{c}{163}
\end{tabular}




\begin{tabular}{|l|l|l|l|l|l|l|}
\hline Greece & 3 & 4,69 & & & & \\
\hline Tunisia & 4 & 4,69 & & & & \\
\hline France & 5 & & 4,46 & & & \\
\hline Turkey & 6 & & 4,15 & & & \\
\hline Italy & 7 & & 3,85 & & & \\
\hline Eygpt & $\mathbf{8}$ & & & 3,38 & & \\
\hline
\end{tabular}

There are five criteria related to sub-factors of Prioritization of Tourism. Comparative cases of destinations are at the following in terms of these criteria;

As it is seen at Table 3, Greece and Tunisia have got Very Well competitive position rather than other destinations for Part of Total State's Budget which is separated to tourism. Contrastly, Spain, Italy, France and Turkey have got Bad competitive position.

Table 3. The Share of Total State's Budget Which Is Separated to Tourism (\%)

\begin{tabular}{|l|l|l|l|l|l|l|}
\hline & $\begin{array}{l}\text { Ranking } \\
\text { of } \\
\text { Countries }\end{array}$ & $\begin{array}{l}\text { Very } \\
\text { Well }\end{array}$ & Well & Medium & Bad & Very Bad \\
\hline Greece & 1 & 5 & & & & \\
\hline Tunisia & 2 & 4,68 & & & & \\
\hline Egypt & 3 & & 4,37 & & & \\
\hline Morocco & 4 & & & & 2,34 & \\
\hline Spain & 5 & & & & & 0,89 \\
\hline Italy & 6 & & & & & 0,44 \\
\hline France & 7 & & & & & 0,32 \\
\hline Turkey & 8 & & & & & 0,06 \\
\hline
\end{tabular}

Results of Evaluation for Activity of Marketing and Branding Campaigns That Countries Make to Attract Tourist are involved in Table 4. According to it, Spain, Morocco, France and Turkey have got Very Well competitive position rather than other destinations for marketing and branding efforts that they make to attract tourist.

\section{Table 4. Activity of Marketing and Branding Campaigns}

\begin{tabular}{|l|l|l|l|l|l|l|}
\hline & $\begin{array}{l}\text { Ranking } \\
\text { of } \\
\text { Countries }\end{array}$ & $\begin{array}{l}\text { Very } \\
\text { Well }\end{array}$ & Well & Medium & Bad & Very Bad \\
\hline Spain & 1 & 5 & & & & \\
\hline Morocco & 2 & 5 & & & & \\
\hline France & 3 & 4,72 & & & & \\
\hline \multicolumn{7}{|c|}{164}
\end{tabular}




\begin{tabular}{|l|l|l|l|l|l|l|}
\hline Turkey & $\mathbf{4}$ & $\mathbf{4 , 5 3}$ & & & & \\
\hline Greece & $\mathbf{5}$ & & $\mathbf{4 , 3 4}$ & & & \\
\hline Tunisia & $\mathbf{6}$ & & $\mathbf{4 , 1 5}$ & & & \\
\hline Italy & $\mathbf{7}$ & & & 3,40 & & \\
\hline Egypt & $\mathbf{8}$ & & & 3,11 & & \\
\hline
\end{tabular}

At Table 5, Values related to Extensity of Annual Tourism Data of destinations are involved by national information source which has got formal quality. According to it, Spain and Turkey have got Very Well competitive position in terms of extensity of annual tourism data.

Table 5. Extensity of Amnual Tourism Data

\begin{tabular}{|l|l|l|l|l|l|l|}
\hline & $\begin{array}{l}\text { Ranking } \\
\text { of } \\
\text { Countries }\end{array}$ & $\begin{array}{l}\text { Very } \\
\text { Well }\end{array}$ & Well & Medium & Bad & Very Bad \\
\hline Spain & 1 & 5 & & & & \\
\hline Turkey & 2 & 4,66 & & & & \\
\hline Fransa & 3 & & 4,14 & & & \\
\hline Italy & 4 & & 3,97 & & & \\
\hline Morocco & 5 & & 3,92 & & & \\
\hline Egypt & 6 & & 3,79 & & & \\
\hline Greece & 7 & & & 3,10 & & \\
\hline Tunisia & 8 & & & 2,76 & & \\
\hline
\end{tabular}

At Table 6, Values of destinations belonging to the criteria Supplying Monthly /Three-Month Tourism Data in Time are involved by national source which has got formal quality. According to it, while Egypt has got Well position to supply data in time, other destinations are seen to be at Very Well position.

Table 6. Supplying Data in Time

\begin{tabular}{|l|l|l|l|l|l|l|}
\hline & $\begin{array}{l}\text { Ranking } \\
\text { of } \\
\text { Countries }\end{array}$ & $\begin{array}{l}\text { Very } \\
\text { Well }\end{array}$ & Well & Medium & Bad & Very Bad \\
\hline Turkey & 1 & 5 & & & & \\
\hline Morocco & 2 & 5 & & & & \\
\hline Spain & 3 & 4,87 & & & & \\
\hline Tunisia & 4 & 4,87 & & & & \\
\hline France & 5 & 4,74 & & & & \\
\hline Italy & 6 & 4,62 & & & & \\
\hline Greece & 7 & 4,62 & & & & \\
\hline
\end{tabular}




\begin{tabular}{|l|l|l|l|l|l|l|}
\hline Egypt & $\mathbf{8}$ & & $\mathbf{4 , 4 9}$ & & & \\
\hline
\end{tabular}

At Table 7 , National Tourism Organisation Strategies' Truth Level belonging to destinations is involved. According to it, Spain and France have got Very Well competitive position when they are compared with other destinations about strategies that national tourism organisation applies them.

Table 7. Truth Level of National Tourism Organisation Strategies

\begin{tabular}{|l|l|l|l|l|l|l|}
\hline & $\begin{array}{l}\text { Ranking } \\
\text { of } \\
\text { Countries }\end{array}$ & $\begin{array}{l}\text { Very } \\
\text { Well }\end{array}$ & Well & Medium & Bad & Very Bad \\
\hline Spain & 1 & 5 & & & & \\
\hline France & 2 & 4,95 & & & & \\
\hline Italy & 3 & & 4,42 & & & \\
\hline Morocco & 4 & & 4,22 & & & \\
\hline Greece & 5 & & 3,72 & & & \\
\hline Egypt & 6 & & & 3,17 & & \\
\hline Turkey & 7 & & & 3,02 & & \\
\hline Tunisia & 8 & & & & 2,21 & \\
\hline
\end{tabular}

Second sub-factor related to TPEC Index is International Openness. Comparative cases of destinations are at the following in terms of these sub-factors;

As it is seen at Table 8, Morocco, Tunisia and Egypt have got Medium competitive position, Turkey has got Well competitive position and other destinations have got Very Well competitive position in terms of sub-factors in International Openness.

Table 8. International Openness

\begin{tabular}{|l|l|l|l|l|l|l|}
\hline & $\begin{array}{l}\text { Ranking } \\
\text { of } \\
\text { Countries }\end{array}$ & $\begin{array}{l}\text { Very } \\
\text { Well }\end{array}$ & Well & Medium & Bad & Very Bad \\
\hline France & 1 & 5 & & & & \\
\hline Greece & 2 & 4,85 & & & & \\
\hline Italy & 3 & 4,85 & & & & \\
\hline Spain & 4 & 4,66 & & & & \\
\hline Turkey & 5 & & 3,96 & & & \\
\hline Morocco & 6 & & & 3,04 & & \\
\hline Tunisia & 7 & & & 2,82 & & \\
\hline Egypt & 8 & & & 2,57 & & \\
\hline
\end{tabular}


There are three criteria related to sub-factors of International Openness. Comparative Cases of destinations are at the following in terms of these criteria;

At Table 9, Visa Requirements for Entry to Destination Country was evaluated. After the evaluation was made as 100= visa is required for all countries, $0=$ visa condition is not required for all countries $(\mathrm{WEF}, 2015)$, it was turned into five point likert scale. According to it, Morocco and Turkey have got Very Well competitive position, other destinations can be said to have Well competitive position in terms of visa requirements.

Table 9. Visa Requirements

\begin{tabular}{|l|l|l|l|l|l|l|}
\hline & $\begin{array}{l}\text { Ranking of } \\
\text { Countries }\end{array}$ & $\begin{array}{l}\text { Very } \\
\text { Well }\end{array}$ & Well & Medium & Bad & Very Bad \\
\hline Morocco & 1 & 5 & & & & \\
\hline Turkey & 2 & 4,67 & & & & \\
\hline France & 3 & & 3,83 & & & \\
\hline Spain & 4 & & 3,83 & & & \\
\hline Greece & 5 & & 3,83 & & & \\
\hline Tunisia & 6 & & 3,83 & & & \\
\hline Italy & 7 & & 3,67 & & & \\
\hline Egypt & 8 & & 3,67 & & & \\
\hline
\end{tabular}

At Table 10, destinations' Bilateral Ait Services Contracts' Case is evaluated. According to it, France has got Very Well competitive position in terms of bilateral air services contracts.

Table 10. Bilateral Air Services Contracts

\begin{tabular}{|l|l|l|l|l|l|l|}
\hline & $\begin{array}{l}\text { Ranking of } \\
\text { Countries }\end{array}$ & $\begin{array}{l}\text { Very } \\
\text { Well }\end{array}$ & Well & Medium & Bad & Very Bad \\
\hline France & 1 & 5 & & & & \\
\hline Italy & 2 & & 4,26 & & & \\
\hline Turkey & 3 & & 4,15 & & & \\
\hline Greece & 4 & & 4,12 & & & \\
\hline Tunisia & 5 & & 3,75 & & & \\
\hline Morocco & 6 & & 3,68 & & & \\
\hline Spain & 7 & & & 3,05 & & \\
\hline Egypt & 8 & & & 2,57 & & \\
\hline
\end{tabular}

At Table 11, destinations are evaluated by "Regional Trade Contracts " that they make. According to it, Morocco, Egypt and Tunisia have got Very Bad competitive position , Turkey has got Bad competitive position and France, Spain, Italy and Greece cam be said to have got Very Well competitive position in terms of regional trade contracts.

Table 11. Regional Trade Conctracts

\begin{tabular}{|l|l|l|l|l|l|l|}
\hline & $\begin{array}{l}\text { Ranking of } \\
\text { Countries }\end{array}$ & $\begin{array}{l}\text { Very } \\
\text { Well }\end{array}$ & Well & Medium & Bad & Very Bad \\
\hline France & 1 & 5 & & & & \\
\hline Spain & 2 & 5 & & & & \\
\hline Italy & 3 & 5 & & & & \\
\hline Greece & 4 & 5 & & & & \\
\hline
\end{tabular}




\begin{tabular}{|l|l|l|l|l|l|l|}
\hline Turkey & 5 & & & & 2,17 & \\
\hline Morocco & 6 & & & & & 0,76 \\
\hline Egypt & 7 & & & & & 0,65 \\
\hline Tunisia & 8 & & & & & 0,65 \\
\hline
\end{tabular}

Third of sub-factors related to TPEC Index is Price Competition. Comparative cases of destinations are at the following in terms of these sub-factors.

At Table 12, destinations' competitive positions were evaluated in terms of Price Competition. According to it, it can be said that most disadvantageous is France in terms of Price competition, most advantageous is Egypt and Tunisia, in terms of price competition.

\section{Table 12. Price Competition}

\begin{tabular}{|l|l|l|l|l|l|l|}
\hline & $\begin{array}{l}\text { Ranking of } \\
\text { Countries }\end{array}$ & $\begin{array}{l}\text { Very } \\
\text { Well }\end{array}$ & Well & Medium & Bad & Very Bad \\
\hline Egypt & 1 & 5 & & & & \\
\hline Tunisia & 2 & 4,53 & & & & \\
\hline Morocco & 3 & & 3,99 & & & \\
\hline Turkey & 4 & & 3,53 & & & \\
\hline Spain & 5 & & & 3,41 & & \\
\hline Greece & 6 & & & 3,17 & & \\
\hline Italy & 7 & & & 2,82 & & \\
\hline France & 8 & & & & 2,38 & \\
\hline
\end{tabular}

There are four criteria related to sub-factors of price competition. Comparative cases of destinations are at the following in terms of these criteria;

At Table 13, values related to Ticket Taxes and Airport Prices for destinations are seen. According to it, it can be said that most disadvantageous destination is France in terms of ticket taxes and airport destination.

Table 13. Ticket Taxes and Airport Price

\begin{tabular}{|l|l|l|l|l|l|l|}
\hline & $\begin{array}{l}\text { Ranking } \\
\text { of } \\
\text { Countries }\end{array}$ & $\begin{array}{l}\text { Very } \\
\text { Well }\end{array}$ & Well & Medium & Bad & Very Bad \\
\hline Turkey & 1 & 5 & & & & \\
\hline Egypt & 2 & 4,72 & & & & \\
\hline Tunisia & 3 & 4,68 & & & & \\
\hline Spain & 4 & 4,65 & & & & \\
\hline Morocco & $\mathbf{5}$ & 4,57 & & & & \\
\hline Greece & 6 & 4,54 & & & & \\
\hline Italy & 7 & & 4,23 & & & \\
\hline France & 8 & & & 3,48 & & \\
\hline
\end{tabular}

At Table 14, comparison of competitive position is involved in terms of Average Room Prices Which Is Calculated for First Class Brand Hotel related to destinations. According to it, while Egypt has got Very Well competitive position, it is seen that Italy and France have got Bad competitive position in terms of hotel room prices.

Table 14. Prices for Hotel Rooms 


\begin{tabular}{|l|l|l|l|l|l|l|}
\hline & $\begin{array}{l}\text { Ranking } \\
\text { of } \\
\text { Countries }\end{array}$ & $\begin{array}{l}\text { Very } \\
\text { Well }\end{array}$ & Well & Medium & Bad & Very Bad \\
\hline Egypt & 1 & 5 & & & & \\
\hline Tunisia & 2 & & 3,88 & & & \\
\hline Spain & 3 & & & 3,21 & & \\
\hline Morocco & 4 & & & 3,18 & & \\
\hline Turkey & 5 & & & 2,93 & & \\
\hline Greece & 6 & & & 2,77 & & \\
\hline Italy & 7 & & & & 2,07 & \\
\hline France & 8 & & & & 1,67 & \\
\hline
\end{tabular}

At Table 15, destinations' competitive positions are evaluated by the criteria Dollar-denominated Purchasing Parity. According to it, it can be said that France has got Very Bad competitive position and Greece, Spain and Italy have got Bad competitive position in terms of conversion rate of formal exchange rate purchasing power parity (PPP). Other destinations have got Well and Very Well competitive positions.

Table 15. Parity of Purchasing

\begin{tabular}{|l|l|l|l|l|l|l|}
\hline & $\begin{array}{l}\text { Ranking of } \\
\text { Countries }\end{array}$ & $\begin{array}{l}\text { Very } \\
\text { Well }\end{array}$ & Well & Medium & Bad & Very Bad \\
\hline Egypt & 1 & 5 & & & & \\
\hline Tunisia & 2 & 4,55 & & & & \\
\hline Morocco & 3 & & 4,09 & & & \\
\hline Turkey & 4 & & 3,64 & & & \\
\hline Greece & 5 & & & & 2,27 & \\
\hline Spain & 6 & & & & 1,82 & \\
\hline Italy & 7 & & & & 1,82 & \\
\hline France & 8 & & & & & 1,36 \\
\hline
\end{tabular}

At Table 16, evaluation of destinations' competitive positions for Price Level of Fuel is involved. According to it, Italy has got Very Well competitive position in terms of fuel prices. Turkey has got Bad competitive position. Contrastly, it can be said that Egypt and Tunisia have got Very Well competitive position.

Table 16. Price Level of Fuel

\begin{tabular}{|l|l|l|l|l|l|l|}
\hline & $\begin{array}{l}\text { Ranking of } \\
\text { Countries }\end{array}$ & $\begin{array}{l}\text { Very } \\
\text { Well }\end{array}$ & Well & Medium & Bad & Very Bad \\
\hline Morocco & 1 & 5 & & & & \\
\hline Tunisia & 2 & 4,73 & & & & \\
\hline Morocco & 3 & & 4,05 & & & \\
\hline Spain & 4 & & 4,05 & & & \\
\hline France & 5 & & 3,86 & & & \\
\hline Greece & 6 & & & 2,76 & & \\
\hline Turkey & 7 & & & & 1,69 & \\
\hline Italy & 8 & & & & & 0,62 \\
\hline
\end{tabular}


Fourth of sub-factors related to TPEC Index is Environmental Sustainability. Comparative cases of destinations are at the following in terms of these sub-factors;

At Table 17, competitive positions of destinations are evaluated in terms of Environmental Sustainability. According to it, it can be said that destinations have not got competitive supremacy difference which would be accepted as important in terms of environmental sustainability.

Table 17. Environmental Sustainability

\begin{tabular}{|l|l|l|l|l|l|l|}
\hline & $\begin{array}{l}\text { Ranking of } \\
\text { Countries }\end{array}$ & $\begin{array}{l}\text { Very } \\
\text { Well }\end{array}$ & Welll & Medium & Bad & Very Bad \\
\hline France & 1 & 5 & & & & \\
\hline Spain & 2 & 4,93 & & & & \\
\hline Italy & 3 & 4,65 & & & & \\
\hline Tunisia & 4 & 4,52 & & & & \\
\hline Greece & 5 & & 4,49 & & & \\
\hline Morocco & 6 & & 4,38 & & & \\
\hline Egypt & 7 & & 4,27 & & & \\
\hline Turkey & 8 & & 4,10 & & & \\
\hline
\end{tabular}

7 criteria related to sub-factors of Environmental Sustainability were received for consideration. Comparative cases of destinations are at the following in terms of these criteria;

At Table 18, Strict Controls on Applications of Environment Arrangements of destinations are evaluated. According to it, France applies more strict control on environment arrangements applications rather than other destinations. Egypt shows Bad performance on this subject rather than other destinations.

Table 18. Applications for Environment Arrangement

\begin{tabular}{|l|l|l|l|l|l|l|}
\hline & $\begin{array}{l}\text { Ranking of } \\
\text { Countries }\end{array}$ & $\begin{array}{l}\text { Very } \\
\text { Well }\end{array}$ & Well & Medium & Bad & Very Bad \\
\hline France & 1 & 5 & & & & \\
\hline Spain & 2 & & 4,42 & & & \\
\hline Italy & 3 & & 4,33 & & & \\
\hline Greece & 4 & & 3,85 & & & \\
\hline Turkey & 5 & & 3,85 & & & \\
\hline Tunisia & 6 & & 3,75 & & & \\
\hline Morocco & 7 & & 3,65 & & & \\
\hline Egypt & 8 & & & & 2,12 & \\
\hline
\end{tabular}

At Table 19, evaluation results related to how governments' efforts are seen for Tourism Sustainability on destinations are involved. According to it, Government's efforts about sustainability of sector development are evaluated as Very Well in Morocco, France, Spain and Turkey.

Table 19. Sustainability of Tourism Development

\begin{tabular}{|l|l|l|l|l|l|l|}
\hline & $\begin{array}{l}\text { Ranking of } \\
\text { Countries }\end{array}$ & $\begin{array}{l}\text { Very } \\
\text { Well }\end{array}$ & Well & Medium & Bad & Very Bad \\
\hline Morocco & 1 & 5 & & & & \\
\hline France & 2 & 4,71 & & & & \\
\hline Spain & 3 & 4,71 & & & & \\
\hline Turkey & 4 & 4,61 & & & & \\
\hline Greece & 5 & & 4,22 & & & \\
\hline
\end{tabular}




\begin{tabular}{|l|l|l|l|l|l|l|}
\hline Tunisia & 6 & & 4,22 & & & \\
\hline Egypt & 7 & & 3,53 & & & \\
\hline Italy & 8 & & & 3,04 & & \\
\hline
\end{tabular}

At Table 20, evaluation of competitive position related to weather pollution on destinations is involved. According to it, while Morocco has got Very Well competitive position on evaluation related to weather pollution, Turkey, Italy and Egypt have got Bad competitive position.

Table 20. Particles Substance Concentration

\begin{tabular}{|l|l|l|l|l|l|l|}
\hline & $\begin{array}{l}\text { Ranking of } \\
\text { Countries }\end{array}$ & $\begin{array}{l}\text { Very } \\
\text { Welll }\end{array}$ & Well & Medium & Bad & Very Bad \\
\hline Morocco & 1 & 5 & & & & \\
\hline Tunisia & 2 & & 3,80 & & & \\
\hline Spain & 3 & & & 3,46 & & \\
\hline France & 4 & & & 3,31 & & \\
\hline Greece & 5 & & & 3,06 & & \\
\hline Turkey & 6 & & & & 2,26 & \\
\hline Italy & 7 & & & & 2,20 & \\
\hline Eygpt & 8 & & & & 2,09 & \\
\hline
\end{tabular}

At Table 21, evaluation of competitive position is involved by Number of Environment Contracts That countries as subject to the study are Certified. According to it, Tukery has got worst competitive position among countries on Mediterranean Basin in terms of environment contracts that it signs.

\section{Table 21. Number of Certified Environment Contracts}

\begin{tabular}{|l|l|l|l|l|l|l|}
\hline & $\begin{array}{l}\text { Ranking of } \\
\text { Countries }\end{array}$ & $\begin{array}{l}\text { Very } \\
\text { Well }\end{array}$ & Well & Medium & Bad & Very Bad \\
\hline Spain & 1 & 5 & & & & \\
\hline France & 2 & 4,80 & & & & \\
\hline Greece & 3 & 4,60 & & & & \\
\hline Italy & 4 & & 4,40 & & & \\
\hline Morocco & 5 & & 4,40 & & & \\
\hline Eygpt & 6 & & 4,20 & & & \\
\hline Tunisia & 7 & & 3,80 & & & \\
\hline Turkey & 8 & & & 3,20 & & \\
\hline
\end{tabular}

At Table 22, destinations' competitive positions related to Baseline Water Stress are evaluated. Baseline water stress provides information about competition level among users of water ( industry, agriculture and municipalities ) and decrease rate related to water sources. According to it, Spain and Morocco have got Bad competitive position in terms of water sources. Egypt has got Very Well , other destinations have got Well competitive position.

\section{Table 22. Baseline Water Stress}

\begin{tabular}{|l|l|l|l|l|l|l|}
\hline & $\begin{array}{l}\text { Ranking of } \\
\text { Countries }\end{array}$ & $\begin{array}{l}\text { Very } \\
\text { Well }\end{array}$ & Well & Medium & Bad & Very Bad \\
\hline Egypt & 1 & 5 & & & & \\
\hline France & 2 & & 4,40 & & & \\
\hline Turkey & 3 & & 4,05 & & & \\
\hline Greece & 4 & & 4,05 & & & \\
\hline Italy & 5 & & 3,93 & & & \\
\hline Tunisia & 6 & & 3,57 & & & \\
\hline \\
171 \\
\hline
\end{tabular}




\begin{tabular}{|l|l|l|l|l|l|l|}
\hline Spain & 7 & & & & 2,14 & \\
\hline Morocco & 8 & & & & 1,55 & \\
\hline
\end{tabular}

At Table 23, destinations' competitive positions are evaluated in terms of Species under Threat. This evaluation is made as rate of species which are under critical threat, under threat and unguarded to total mamals, birds and amphibians. According to it, France ihas got Very Well, Turkey has got Bad competitive position.

Table 23. Species Under Threat

\begin{tabular}{|l|l|l|l|l|l|l|}
\hline & $\begin{array}{l}\text { Ranking of } \\
\text { Countries }\end{array}$ & $\begin{array}{l}\text { Very } \\
\text { Well }\end{array}$ & Well & Medium & Bad & Very Bad \\
\hline France & 1 & 5 & & & & \\
\hline Italy & 2 & & 4,22 & & & \\
\hline Tunisia & 3 & & 4,03 & & & \\
\hline Greece & 4 & & 3,77 & & & \\
\hline Egypt & 5 & & 3,70 & & & \\
\hline Spain & 6 & & & 3,44 & & \\
\hline Fas & 7 & & & 3,31 & & \\
\hline Turkey & 8 & & & & 2,40 & \\
\hline
\end{tabular}

At Table 24, destinations' competitive positions are evaluated by waste waterwater refinement criteria. According to it, when Spain , Italy, France and Greece are compared with other destinations subject to the study, they have got Very Well competitive performance about waste water refinement .

Table 24. Refinement of Waste Water

\begin{tabular}{|l|l|l|l|l|l|l|}
\hline & $\begin{array}{l}\text { Ranking of } \\
\text { Countries }\end{array}$ & $\begin{array}{l}\text { Very } \\
\text { Well }\end{array}$ & Well & Medium & Bad & Very bad \\
\hline Spain & 1 & 5 & & & & \\
\hline Italy & 2 & 4,92 & & & & \\
\hline France & 3 & 4,52 & & & & \\
\hline Greece & 4 & 4,70 & & & & \\
\hline Eygpt & 5 & & & 2,67 & & \\
\hline Turkey & 6 & & & 2,63 & & \\
\hline Morocco & 7 & & & & 2,12 & \\
\hline Tunisia & 8 & & & & 1,50 & \\
\hline
\end{tabular}

5.2. The Relation between Tourism Policy and Enabling Conditions Index and Number of Tourist, Income of Tourism

Destinations' 2014 year international tourism incomes and tourist numbers with TPEC Index values which are examined within the examination are seen at Table 26.

Table 26. Counties' TPEC, Number of Tourist and Income of Tourism

\begin{tabular}{|l|l|l|l|}
\hline Countries & TPEC. & Number of Tourist (million) & Income of Tourism (thousand \$) \\
\hline Egypt & 4,23 & 9.174 & 6.047 \\
\hline Greece & 4,39 & 17.920 & 16.139 \\
\hline Italy & 4,14 & 47.704 & 43.912 \\
\hline Spain & 4,66 & 60.661 & 62.565 \\
\hline France & 4,25 & 84.726 & 56.686 \\
\hline Tunisia & 4,28 & 6.269 & 2.190 \\
\hline \multicolumn{3}{|c|}{172} \\
\hline
\end{tabular}




\begin{tabular}{|l|l|l|l|}
\hline Turkey & 3,98 & 37.795 & 27.997 \\
\hline Morocco & 4,21 & 10.046 & 6.850 \\
\hline
\end{tabular}

Source: (WEF,2015)

Correlation analysis was made as to evaluate the relation between TPEC Index and Number of Tourist, Tourism Income. Correlation analysis is a statistical method which reveal direction, degree and importance of the relation among variances. Variances were obtained by proportional or interval scales and if it is suitable to normal distributors, Pearson correlation analysis is made. Variances were obtained by proportional or interval scales but if it does not suitable to normal distribution, Spearman correlation analysis is made. Results of normality test which was made were given at Table 27.

\section{Table 27. Normality Test Results}

\begin{tabular}{|c|c|c|c|c|c|c|}
\hline & \multicolumn{6}{|c|}{ Kolmogorov-SmirnovalShapiro-Wilk } \\
\hline & Statistic & & Sig. & Statis & $\mathrm{ddfS}$ & \\
\hline $\begin{array}{l}\text { Number of Touris } \\
\text { and TPEC }\end{array}$ &, 217 & 8 & $200^{*}$ & 896 & & 264 \\
\hline & 226 & 8 & $200^{*}$ & 927 & 8,4 & 489 \\
\hline Income & 187 & 8 & $200^{*}$ & 890 & 8,2 & 233 \\
\hline $\begin{array}{l}\text { Tourism } \\
\text { TPEC }\end{array}$ & ,226 & 8 & $200^{*}$ & 927 & & 489 \\
\hline
\end{tabular}

*. This is a lower bound of the true significance

a. Lilliefors Significance Correction

According to these results, TPEC with International Tourist Number and TPEC with International Tourism Income variances are suitable to normal distribution. In this case, Pearson correlation analysis can be applied.

Table 28. The Relation between TPEC and Number of Tourist and Income of Tourism

\begin{tabular}{|l|l|l|}
\hline TPEC & $\begin{array}{l}\text { Number } \\
\text { Tourist }\end{array}$ & $\begin{array}{c}\text { of } \\
\text { lncome } \\
\text { Tourism }\end{array}$ \\
\hline$r$ &, 341 &, 169 \\
\cline { 2 - 3 } Sig. & \multirow{4}{*}{$409^{*}$} &, $689^{*}$ \\
\hline
\end{tabular}

" $p>0,05$

Analysis result related to whether a relation is or not among variances were given at Table 28 . According to it, there is not a statistical relation between TPEC with International Tourist Number and TPEC with International Tourism Income.

\section{Conclusion}

On this study, competitive position of eight destinations on Mediterranean Basin ( Turkey, Greece, Italy, France, Spain, Egypt, Tunisia and Morocco) was compared within 4 main criteria (Prioritization of Tourism, International Openness, Price Competition and Environmental Sustainability ) as data of Tourism Policy and Enabling Conditions Index of World Economic Forum Travel and Tourism Competitiveness Index was used. Moreover, on the study, it was examined whether there is a relation between international tourism incomes and tourist number with TPEC.

Most competitive first three destinations are respectively Spain, Greece and Tunisia in terms of TPEC general evaluation. Moreover, competitive positions of destinations which were examined within the concept of the study differ in 4 sub-factors. Furthermore, when eight destinations on Mediterranean Basin are evaluated, there is not a relation between TPEC and Tourism Income and Tourist Number. Moreover, when total 141 countries' TPEC and Tourism Income and Tourist Number involved in WEF's 2015 report were analyzed, it is seen that there is a relation as meaningful in terms of statistical and in positive direction among variances.

This study is important as it defines Travel and Tourism Competitiveness Index and it shows how to analyze secondary data which are obtained from index and connected sub-indexes for active comparative analysis. Further researchers can 
make evaluations related to different destinations as following and developing method and evaluations which were used on the study.

Restriction which requires to be considered about the study is that reliability and validity of findings revaled on this study are based on reliability and validity of data on Travel and Tourism Competitiveness Index as World Economic Forum 's data was used on this study.

\section{References}

AALEP (Association of Accredited Public policy Advocates to the European Union), (2015), Effectıveness Of Marketıng To Attract Tourısts, http://www.aalep.eu/effectiveness-marketing-attract-tourists,22/01/2016

Anze,C.,Yunting,L.Young,C.Y.(2015), The Principles of Geotuorism, Science Pres,Beijing.

Chatziantoniou, I., Filis, G., Eeckels, B., \& Apostolakis, A. (2013). Oil Prices, Tourism Income And Economic Growth: A Structural VAR Approach For European Mediterranean Countries. Tourism Management, 36, 331-341.

Crotti,R.Mısrahı,T. (2015), The Travel \& Tourism Competitiveness Index: T\&T as a Resilient Contribution to National Development, World Economic Forum.

Damnjanovic,V.Kravic,M. and AbdulRazek,T.,(2009), Branding Strategiy of Mediterranean Region as a Tourism Destination, Creativity, Innovation an Management International Conference, Tunisia,25-28 November.

Dwyer,L.Forsyth,P.and Rao,P.,(2001), PPPs and The Price Competitiveness of International Tourism Destinations, OECD and The World Bank Group, Washington.

Falzon,J.(2012), The Price Competitive Position of Mediterranean Countries in Tourism: Evidence From the Thomson Brochure, Tourism Management,33,1080-1092.

Gassert,F.Reig,P.,Luo,T. and Maddocks,A. (2013) Aqueduct Country And River Basin Rankings A Weighted Aggregation Of Spatially Distinct Hydrological,World Resources Institute.

IATA, Tourism Tax, https://www.iata.org/policy/Documents/tourism-tax.pdf.;

Kozak, M. and Rimmington, M. (1999), "Measuring Tourist Destination Competitiveness: Conceptual Considerations and Empirical Findings", International Journal of Hospitality Management, 18(3): 273-283.

Öztürk,Y.Uşaklı,A.(2013), Global İnovasyon Endeksi: Akdeniz Çanağındaki destinasyonlara Yönelik Karşılaştırmalı Bir Analiz, 14. Ulusal Turizm Kongresi, Kayseri

Ratnayake, R.(1998),Do Stringent Environmental Regulations Reduce International Competitiveness? Evidence from an Inter-industry Analysis, International Journal of the Economics of Business,Vol.5, No.1,77-96.

Rıfai,T.,(2012), Global Report on Aviation, UNWTO.

The World Bank, World Development Indicators, from http://data.worldbank.org/indicator/EN.ATM.PM25.MC.M3;

TÜIK,(2008), Satınalma Gücü Paritesi, Sorularla Resmi İstatistikler Dizisi-4, Ankara.

UN (United Nations), (2010), International Recommendations for Tourism Statistics 2008, Department of Economic and Social Affairs Statistics Division, United Nations Publication New York.

UNEP and UNWTO, (2005),Making Tourism More Sustainable - A Guide for Policy Makers.

UNWTO ,(2015), Compendium of Tourism Statistic (2015 Edition).

UNWTO, (2016), Visa Openness Report 2015.

World Economic Forum (WEF), (2015), The Travel and Tourism Competitiveness Report 2015, Geneva. 